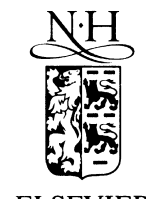

Nuclear Instruments and Methods in Physics Research B 161-163 (2000) 245-249

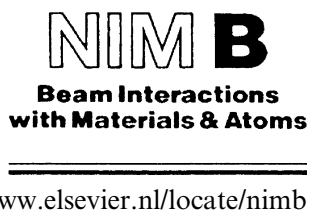

\title{
Molecular information in static SIMS for the speciation of inorganic compounds
}

\author{
R. Van Ham, A. Adriaens *, L. Van Vaeck, R. Gijbels, F. Adams \\ Department of Chemistry, University of Antwerp, Universiteitsplein 1, B-2610, Wilrijk, Belgium
}

\begin{abstract}
This paper presents a systematic study of pure inorganic binary salts using a time-of-flight (TOF) static secondary ion mass spectroscopy (S-SIMS) instrument. The objective was to evaluate the method's capability to achieve molecular speciation of binary salts. The results show the feasibility of direct speciation in a deductive manner without the need for reference spectra. Also ratioing intensities of specific high- $\mathrm{m} / \mathrm{z}$ cluster ions can differentiate compounds with the same elements in different oxidation states. () 2000 Elsevier Science B.V. All rights reserved.
\end{abstract}

PACS: $82.80 \mathrm{Ms} ; 81.20 \mathrm{Rg} ; 33.15 \mathrm{Ta}$

Keywords: Static SIMS; Inorganic speciation; Molecular identification; Binary salts

\section{Introduction}

By aiming at the molecular information of inorganic compounds we intend to address the growing demand from scientific and technological research to specify the local composition of a sample in terms of molecules rather than elements. It is evident that the behaviour and the properties of the bulk and interfaces of materials are governed by the structure and the interactions of molecules. In this context, static secondary ion mass spectroscopy (S-SIMS) emerges as a promising technique. Its potential advantage for mo-

\footnotetext{
${ }^{*}$ Corresponding author. Tel.: +32-3-820-23-77; fax: +32-3820-23-76.

E-mail address: mieke@uia.ua.ac.be (A. Adriaens).
}

lecular speciation i.e. the identification by signals referring directly to intact molecules lies primarily in the use of a low flux ion bombardment resulting in relatively high molecular ion yields. This aspect in combination with the possibility to analyse the top monolayer on a microscopical scale is essential for the analysis of complex and/or locally heterogeneous surfaces. Up to now little has been published on inorganic speciation, this in contrast to the amount of data on organic compounds. Much of the systematic work dates back to the seventies [1-3]. Mass spectral libraries have become available recently $[4,5]$ but contain only a selected range of inorganic compounds. The work on inorganic compounds with S-SIMS in different fields has been reviewed recently [6,7].

The purpose of this paper is to describe positive and negative ion mass spectra from our systematic 
study of binary salts. The feasibility of the deductive identification will be evaluated and the distinction between salts with the same elements in different stoechiometries is of special interest.

\section{Experimental section}

The binary salts used were $\mathrm{LiCl}, \mathrm{NaCl}, \mathrm{KCl}$, $\mathrm{CuCl}, \mathrm{NaBr}, \mathrm{KBr}, \mathrm{NaI}$ and $\mathrm{KI}$. All products (analytical grade) were purchased from common suppliers (Merck, Janssen Chimica, Aldrich Chemical Company) and were used without any additional purification.

The samples were prepared by making a solution of pure compounds $(\sim 0.2 \mathrm{~g})$ in $50 \%$ methanol/ $50 \% \quad \mathrm{H}_{2} 0$. The solution was sprayed (Badger, model 200, Illinois) as aerosol on a flat substrate (Al-foil and Si-wafer) with an airbrush under a nitrogen pressure of approximately 1 bar. The optimization of the sample preparation has been described elsewhere [8].

The analyses were performed with a TOFSIMS IV (Cameca, France) instrument. The TOF-
SIMS IV is a modular ultra high vacuum, high mass resolution, high transmission instrument, based on a reflector type mass analyser with a post acceleration detector, and various types of pulsed primary ion guns. In this work the spectra were taken using the $\mathrm{Ga}^{+}$-liquid metal ion gun (angle $45^{\circ}$ ) which was operated at $25 \mathrm{kV}$ beam voltage in the bunched mode with a pulse width of $20 \mathrm{~ns}$. The analysed area was typically $100 \times 100$ to $300 \times 300 \mu \mathrm{m}^{2}$. Under these conditions, the total primary ion dose for an analysis of $200 \mathrm{~s}$ was below $10^{12}$ ions $/ \mathrm{cm}^{2}$. Measurements were done on the most dense area of the aerosol spots.

\section{Results and discussion}

\subsection{Qualitative information}

One of the questions we have addressed in this study is whether there is a systematic trend in the way ions carry qualitative information. The deductive identification in both positive and negative spectra is an asset for applications.

Table 1

Major peaks in positive and negative mode (minor peaks in italics, most useful peaks in bold)

\begin{tabular}{|c|c|c|}
\hline Compounds & Positive ions & Negative ions \\
\hline LiCl & $\begin{array}{l}\mathrm{Li}^{+}, \mathrm{Li}_{2}^{+}, \mathrm{Li}_{2} \mathrm{O}^{+}, \mathrm{Li}_{2} \mathrm{OH}^{+}, \mathrm{Li}_{3} \mathrm{O}^{+}, \mathrm{LiCl}^{+}, \mathbf{L i C l} . \mathrm{Li}^{+} \\
(\mathrm{LiCl})_{2} \cdot \mathrm{Li}^{+},(\mathrm{LiCl})_{3} \cdot \mathrm{Li}^{+}\end{array}$ & $\begin{array}{l}\mathrm{Cl}^{-}, \mathrm{Cl}_{2}^{-}, \mathrm{HCl} \cdot \mathrm{Cl}^{-}, \mathrm{ClO}^{-}, \mathrm{LiCl}^{-}, \mathbf{L i C l} \cdot \mathrm{Cl}^{-} \\
(\mathrm{LiCl})_{2} \cdot \mathrm{Cl}^{-},(\mathrm{LiCl})_{3} \cdot \mathrm{Cl}^{-}\end{array}$ \\
\hline KCl & $\begin{array}{l}\mathrm{K}^{+}, \mathrm{K}_{2}^{+}, \mathrm{K}_{2} \mathrm{O}^{+}, \mathrm{K}_{2} \mathrm{OH}^{+}, \mathrm{KCl}^{+}, \mathbf{K C l} \cdot \mathbf{K}^{+} \\
(\mathrm{KCl})_{2} \cdot \mathrm{K}^{+},(\mathrm{KCl})_{3} \cdot \mathrm{K}^{+}\end{array}$ & $\mathrm{Cl}^{-}, \mathrm{Cl}_{2}^{-}, \mathrm{ClO}^{-}, \mathrm{KCl}^{-}, \mathbf{K C l} \cdot \mathrm{Cl}^{-},(\mathrm{KCl})_{2} \cdot \mathrm{Cl}^{-}$ \\
\hline $\mathbf{K B r}$ & $\begin{array}{l}\mathrm{K}^{+}, \mathrm{K}_{2}^{+}, \mathrm{K}_{2} \mathrm{O}^{+}, \mathrm{K}_{2} \mathrm{OH}^{+}, \mathrm{K}_{3} \mathrm{O}^{+}, \mathrm{KBr}^{+}, \mathbf{K B r} \cdot \mathbf{K}^{+} \\
(\mathrm{KBr})_{2} \cdot \mathrm{K}^{+},(\mathrm{KBr})_{3} \cdot \mathrm{K}^{+},(\mathrm{KBr})_{4} \cdot \mathrm{K}^{+},(\mathrm{KBr})_{5} \cdot \mathrm{K}^{+} \\
(\mathrm{KBr})_{6} \cdot \mathrm{K}^{+}\end{array}$ & $\begin{array}{l}\mathrm{Br}^{-}, \mathrm{Br}_{2}^{-}, \mathrm{HBr} \cdot \mathrm{Br}^{-}, \mathrm{BrO}^{-}, \mathrm{KBr}^{-}, \mathbf{K B r} \cdot \mathrm{Br}^{-} \\
(\mathrm{KBr})_{2} \cdot \mathrm{Br}^{-},(\mathrm{KBr})_{3} \cdot \mathrm{Br}^{-},(\mathrm{KBr})_{4} \cdot \mathrm{Br}^{-}\end{array}$ \\
\hline KI & $\begin{array}{l}\mathrm{K}^{+}, \mathrm{K}_{2}^{+}, \mathrm{K}_{2} \mathrm{O}^{+}, \mathrm{K}_{2} \mathrm{OH}^{+}, \mathrm{K}_{3} \mathrm{O}^{+}, \mathrm{KI}^{+}, \mathbf{K I} \cdot \mathrm{K}^{+} \\
\mathrm{KI} \cdot \mathrm{K}_{2}^{+},(\mathrm{KI})_{2} \cdot \mathrm{K}^{+},(\mathrm{KI})_{3} \cdot \mathrm{K}^{+},(\mathrm{KI})_{4} \cdot \mathrm{K}^{+} \\
\mathrm{KI} \cdot \mathrm{KOH} \cdot \mathrm{K}^{+}, \mathrm{KI} \cdot \mathrm{KO}^{+}\end{array}$ & $\begin{array}{l}\mathrm{I}^{-}, \mathrm{I}_{2}^{-}, \mathrm{IO}^{-}, \mathrm{KI}^{-}, \mathbf{K I} \cdot \mathbf{I}^{-},(\mathrm{KI})_{2}^{-},(\mathrm{KI})_{2} \cdot \mathrm{I}^{-} \\
(\mathrm{KI})_{3} \cdot \mathrm{I}^{-},(\mathrm{KI})_{4} \cdot \mathrm{I}^{-}\end{array}$ \\
\hline $\mathrm{NaCl}$ & $\begin{array}{l}\mathrm{Na}^{+}, \mathrm{Na}_{2}^{+}, \mathrm{Na}_{2} \mathrm{O}^{+}, \mathrm{Na}_{3} \mathrm{O}^{+}, \mathrm{Na}_{2} \mathrm{OH}^{+}, \mathrm{NaCl}^{+}, \\
\mathrm{NaCl} \cdot \mathrm{Na}^{+},(\mathrm{NaCl})_{2} \cdot \mathrm{Na}^{+},(\mathrm{NaCl})_{3} \cdot \mathrm{Na}^{+}, \\
(\mathrm{NaCl})_{4} \cdot \mathrm{Na}^{+}, \mathrm{NaCl} \cdot \mathrm{NaOH} \cdot \mathrm{Na}, \mathrm{NaCl} \cdot \mathrm{NaO}^{+}\end{array}$ & $\begin{array}{l}\mathrm{Cl}^{-}, \mathrm{Cl}_{2}^{-}, \mathrm{HCl} \cdot \mathrm{Cl}^{-}, \mathrm{ClO}^{-}, \mathrm{NaCl}^{-}, \mathbf{N a C l} \cdot \mathrm{Cl}^{-}, \\
(\mathrm{NaCl})_{2} \cdot \mathrm{Cl}^{-}, \mathrm{NaClOH}{ }^{-}\end{array}$ \\
\hline $\mathrm{NaBr}$ & $\begin{array}{l}\mathrm{Na}^{+}, \mathrm{Na}_{2}^{+}, \mathrm{Na}_{2} \mathrm{O}^{+}, \mathrm{Na}_{3} \mathrm{O}^{+}, \mathrm{Na}_{2} \mathrm{OH}^{+}, \mathrm{NaBr}^{+} \\
\mathrm{NaBr} \cdot \mathrm{Na}^{+},(\mathrm{NaBr})_{2} \cdot \mathrm{Na}^{+},(\mathrm{NaBr})_{3} \cdot \mathrm{Na}^{+} \\
(\mathrm{NaBr})_{4} \cdot \mathrm{Na}^{+}\end{array}$ & $\begin{array}{l}\mathrm{Br}^{-}, \mathrm{Br}_{2}^{-}, \mathrm{HBr} \cdot \mathrm{Br}^{-}, \mathrm{BrO}^{-}, \mathrm{NaBr}^{-}, \mathrm{NaBr} \cdot \mathrm{Br}^{-} \\
(\mathrm{NaBr})_{2} \cdot \mathrm{Br}^{-},(\mathrm{NaBr})_{3} \cdot \mathrm{Br}^{-}, \mathrm{NaBrCl}^{-}\end{array}$ \\
\hline NaI & $\begin{array}{l}\mathrm{Na}^{+}, \mathrm{Na}_{2}^{+}, \mathrm{Na}_{2} \mathrm{O}^{+}, \mathrm{Na}_{3} \mathrm{O}^{+}, \mathrm{Na}_{2} \mathrm{OH}^{+}, \mathrm{NaI}^{+}, \\
\mathrm{NaI} \cdot \mathrm{Na}^{+},(\mathrm{NaI})_{2} \cdot \mathrm{Na}^{+},(\mathrm{NaI})_{3} \cdot \mathrm{Na}^{+},(\mathrm{NaI})_{4} \cdot \mathrm{Na}^{+}, \\
(\mathrm{NaI})_{5} \cdot \mathrm{Na}^{+}, \mathrm{NaI} \cdot \mathrm{NaOH} \cdot \mathrm{Na}^{+}, \mathrm{NaI} \cdot \mathrm{NaO}{ }^{+}\end{array}$ & $\begin{array}{l}\mathrm{I}^{-}, \mathrm{I}_{2}^{-}, \mathrm{IO}^{-}, \mathrm{NaI}^{-}, \mathrm{NaI} \cdot \mathrm{I}^{-}, \mathrm{NaI}_{2} \cdot \mathrm{I}^{-},(\mathrm{NaI})_{2} \cdot \mathrm{I}^{-}, \\
(\mathrm{NaI})_{3} \cdot \mathrm{I}^{-},(\mathrm{NaI})_{4} \cdot \mathrm{I}^{-}\end{array}$ \\
\hline $\mathrm{CuCl}$ & $\begin{array}{l}\mathrm{Cu}^{+}, \mathrm{Cu}_{2}^{+}, \mathrm{Cu}_{2} \mathrm{OH}^{+}, \mathrm{CuCl}^{+}, \mathrm{CuCl} \cdot \mathrm{Cu}^{+} \\
(\mathrm{CuCl})_{2} \cdot \mathrm{Cu}^{+}, \mathrm{CuCl} \cdot \mathrm{CuOH} \cdot \mathrm{Cu}^{+}\end{array}$ & $\begin{array}{l}\mathrm{Cl}^{-}, \mathrm{Cl}_{2}^{-}, \mathrm{HCl} \cdot \mathrm{Cl}^{-}, \mathrm{ClO}^{-}, \mathrm{CuCl}^{-}, \mathbf{C u C l} \cdot \mathrm{Cl}^{-} \\
(\mathrm{CuCl})_{2} \cdot \mathrm{Cl}^{-}, \mathrm{CuCl}_{2} \cdot \mathrm{Cl}^{-},(\mathrm{CuCl})_{3} \cdot \mathrm{Cl}^{-}, \\
\mathrm{CuCl} \cdot \mathrm{HCl} \cdot \mathrm{Cl}^{-}, \mathrm{CuClOH} \mathrm{H}^{-}\end{array}$ \\
\hline
\end{tabular}


Table 1 gives a summary of the major characteristic peaks for the eight analysed salts. An example of a typical $\mathrm{CuCl}$ spectrum in negative mode is shown in Fig. 1. In general, all negative and positive spectra are dominated by fragment ions $\mathrm{Y}^{-}$(namely $\mathrm{Cl}^{-}, \mathrm{Br}^{-}$and $\left.\mathrm{I}^{-}\right)$and $\mathrm{M}^{+}\left(\mathrm{K}^{+}\right.$, $\left.\mathrm{Na}^{+}, \mathrm{Li}^{+}, \mathrm{Cu}^{+}\right)$, but also contain adduct ions $\left((\mathrm{MY})_{\mathrm{n}} \cdot \mathrm{Y}^{-}\right.$and $\left.(\mathrm{MY})_{\mathrm{n}} \cdot \mathrm{M}^{+}\right)$, molecular ions $\left(\mathrm{MY}^{-}\right.$and $\left.\mathrm{MY}^{+}\right)$, cluster ions $\left(\mathrm{MY} . \mathrm{Y}_{2}^{-}\right)$and recombination clusters $\left(\mathrm{Y}_{2}^{-}, \mathrm{M}_{2}^{+}, \mathrm{M}_{2} \mathrm{O}^{+}, \mathrm{MOH} . \mathrm{M}^{+}\right.$, $\left.\mathrm{YO}^{-}, \mathrm{M}_{3} \mathrm{O}^{+}, \mathrm{HY} . \mathrm{Y}^{-}\right)$. The high $\mathrm{m} / z$ ions, which use the original molecule as building blocks, are important for direct speciation.

Adduct ions consisting of the intact molecule and a stable anion or cation, such as $\mathrm{KI} . \mathrm{I}^{-}$and $\mathrm{KI} . \mathrm{K}^{+}$are very intense in all spectra and contain the main information needed for direct speciation (Table 1, in bold). Other ions containing up to four or five times the intact molecule could also be
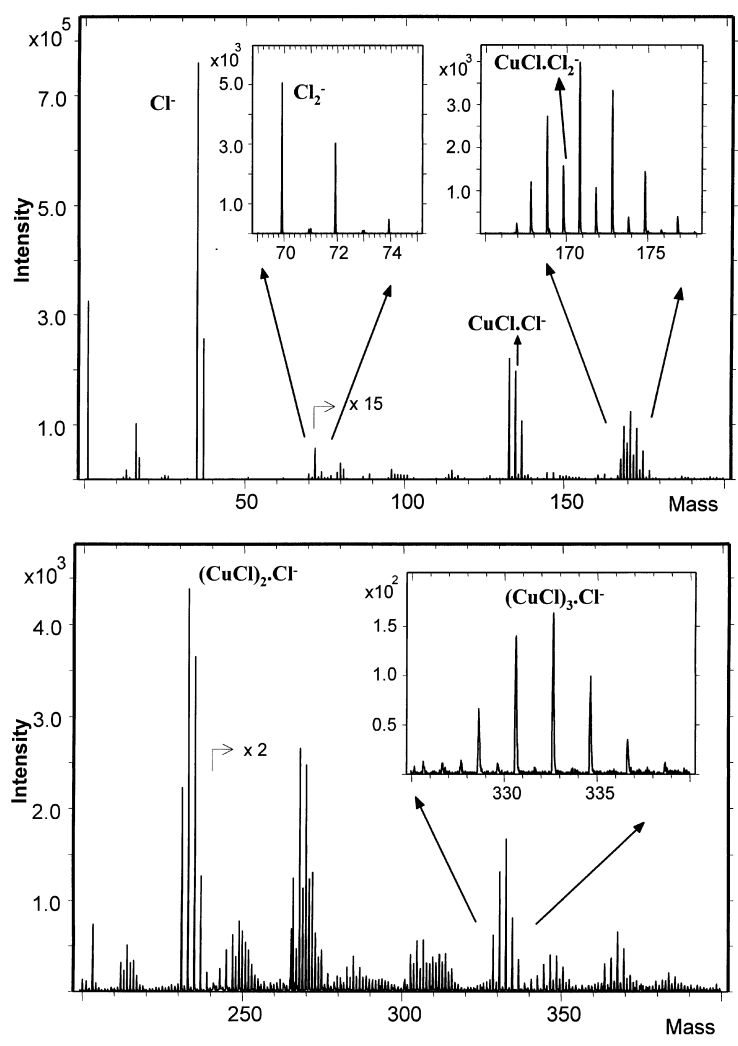

Fig. 1. An example of a typical spectrum in negative mode. observed, but their intensity strongly decreases with increasing number of molecules in the cluster. A correlation is observed between the type of halogen in the binary salt and the relative peak intensities of the adduct ions at higher mass range $(\mathrm{I}>\mathrm{Br}>\mathrm{Cl})$. Molecular ion peaks $\left(\mathrm{MY}^{+}\right.$and $\mathrm{MY}^{-}$) present in all spectra are most intense for iodides but nevertheless are, in general, too low in relative intensity to be useful in speciation analysis of unknown compounds. Also recombination clusters or cluster ions are of little support for the direct speciation of these pure products. The interest of these peaks can perhaps be demonstrated in the analysis of mixtures of the pure compounds, something we are still investigating for the moment.

A few remarkable things we can describe here are that the HY . $\mathrm{Y}^{-}$peak is only present in spectra of chlorides and bromides of the pure salt. Even though the compounds are binary salts and not oxides or oxysalts, a $\mathrm{YO}^{-}$peak is present in all negative spectra. In the positive, the $\mathrm{M}_{2} \mathrm{O}^{+}$, $\mathrm{M}_{2} \mathrm{OH}^{+}$and $\mathrm{M}_{3} \mathrm{O}^{+}$peak are observed except for $\mathrm{CuCl}$ where only $\mathrm{Cu}_{2} \mathrm{OH}^{+}$is detected. Other combinations are seen in lower intensities (Table 1, in italics).

In general, negative ion spectra were found to be more useful for the identification of the salts except for $\mathrm{NaBr}$ and $\mathrm{KBr}$, as the positive spectra tend to contain many intense organic peaks $\left(\mathrm{C}_{n} \mathrm{H}_{n}\right.$ compounds) in comparison to relative low abundance of the specific ions of the pure compound.

Molecular speciation without the use of reference spectra in this class of salts is feasible with TOF-SIMS. Because an intense signal of the intact molecule combined with a stable ion is always present. This information is shown in the negative or positive spectra (or in both modes) depending on the binary salt in the form of $\mathrm{MY} . \mathrm{M}^{+}$and MY . $\mathrm{Y}^{-}$. Intense low $\mathrm{m} / z$-signals characterise the basic elements of the binary salt.

\subsection{Fine speciation $\left(\mathrm{CuCl}\right.$ and $\left.\mathrm{CuCl}_{2}\right)$}

Because $\mathrm{CuCl}$ and $\mathrm{CuCl}_{2}$ are two compounds which produce primarily ions with the same elemental composition, differences of relative peak intensities must be used for distinction. The 
Table 2

Ratios of the peak intensities of $\mathrm{CuCl}$ and $\mathrm{CuCl}_{2}$ at different days

\begin{tabular}{|c|c|c|c|c|}
\hline Ratio & Salt & Day 1 & Day 2 & Day 3 \\
\hline \multirow[t]{2}{*}{$\mathrm{Cl}_{2}^{-} / \mathrm{CuCl} \cdot \mathrm{Cl}^{-}$} & $\mathrm{CuCl}$ & 0.532 & 0.542 & 0.516 \\
\hline & $\mathrm{CuCl}_{2}$ & 1.314 & 1.086 & 0.664 \\
\hline \multirow[t]{2}{*}{$\mathrm{CuCl}^{-} / \mathrm{CuCl} \cdot \mathrm{Cl}^{-}$} & $\mathrm{CuCl}$ & 0.149 & 0.068 & 0.035 \\
\hline & $\mathrm{CuCl}_{2}$ & 0.030 & 0.027 & 0.035 \\
\hline \multirow{2}{*}{$\mathrm{CuCl} \cdot \mathrm{Cl}_{2}^{-} / \mathrm{CuCl} \cdot \mathrm{Cl}^{-}$} & $\mathrm{CuCl}$ & 0.047 & 0.212 & 0.213 \\
\hline & $\mathrm{CuCl}_{2}$ & 0.300 & 0.459 & 0.529 \\
\hline \multirow[t]{2}{*}{$(\mathrm{CuCl})_{2} \cdot \mathrm{Cl}^{-} / \mathrm{CuCl} \cdot \mathrm{Cl}^{-}$} & $\mathrm{CuCl}^{-}$ & 0.152 & 0.294 & 0.293 \\
\hline & $\mathrm{CuCl}_{2}$ & 0.278 & 0.297 & 0.356 \\
\hline \multirow[t]{2}{*}{$(\mathrm{CuCl})_{3} \cdot \mathrm{Cl}^{-} / \mathrm{CuCl} \cdot \mathrm{Cl}^{-}$} & $\mathrm{CuCl}$ & 0.016 & 0.051 & 0.049 \\
\hline & $\mathrm{CuCl}_{2}$ & 0.054 & 0.055 & 0.068 \\
\hline
\end{tabular}

relative intensities are varying in time but what is important is that the tendency of the relative intensities is consistent in time on the condition that the adduct ion intensities are normalised to adduct ions instead of fragment ions or recombination clusters (see Table 2). Day-to-day variations of these ratios make recording of reference spectra on the same day and under the same conditions mandatory.

In Fig. 2 the ratio between the peak intensity of $\mathrm{Cl}_{2}^{-}, \quad \mathrm{CuCl}^{-}, \quad \mathrm{CuCl} \cdot \mathrm{Cl}_{2}^{-}, \quad(\mathrm{CuCl})_{2} . \mathrm{Cl}^{-}$, $(\mathrm{CuCl})_{3} \cdot \mathrm{Cl}^{-}$and $\mathrm{CuCl} \cdot \mathrm{Cl}^{-}$is calculated for both substances measured under static conditions. Under dynamic conditions the results show the same tendency. It can be seen that the critical differences between the static spectra lie in the relative intensities of the adduct ions. As to the

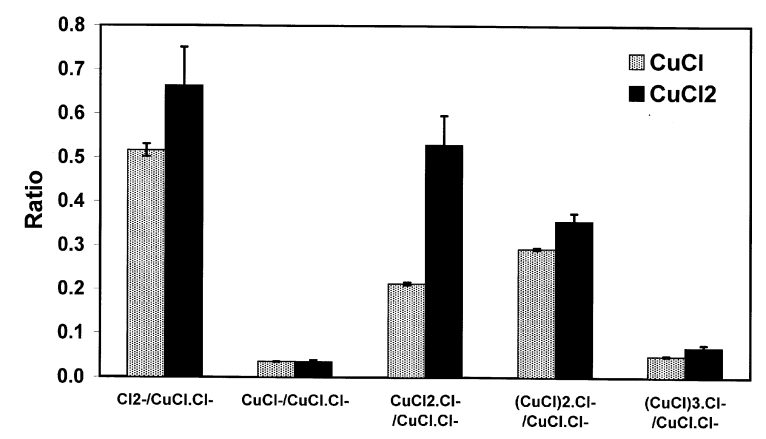

Fig. 2. The ratio between the peak intensity of $\mathrm{Cl}_{2}^{-}, \mathrm{CuCl}^{-}$, $\mathrm{CuCl} \cdot \mathrm{Cl}_{2}^{-},(\mathrm{CuCl})_{2} \cdot \mathrm{Cl}^{-},(\mathrm{CuCl})_{3} \cdot \mathrm{Cl}^{-}$and $\mathrm{CuCl} \cdot \mathrm{Cl}^{-}$calculated for both substances measured under static conditions. negative ions, $\mathrm{CuCl}$ yields a smaller $\mathrm{CuCl}_{2} \cdot \mathrm{Cl}^{-}$ peak relative to the adduct ion $\mathrm{CuCl} . \mathrm{Cl}^{-}$, and therefore this peak ratio can be used to distinguish $\mathrm{CuCl}$ from $\mathrm{CuCl}_{2}$.

\section{Conclusions}

In this work, TOF-SIMS was applied to pure binary salts. Spectra in both negative and positive mode reveal that the qualitative information for molecular speciation without the use of reference spectra in this class of salts with TOF-SIMS is sufficient: an intense signal of the intact molecule combined with a stable ion is always present. Fine speciation of $\mathrm{CuCl}$ and $\mathrm{CuCl}_{2}$ is feasible by ratioing the proper adduct ions, meaning that normalization of adduct ion peaks to adduct ions instead of recombination clusters is essential to extract molecular information from spectra. Later on we will apply this systematic approach to mixtures of more complex inorganic compounds under ion bombardment.

\section{Acknowledgements}

This work was supported in part by the Belgian Office for Scientific, Technical and Cultural Affairs (IUAP 4/10) and by FWO, Brussels, Belgium (Research Project G.0090.98). A.A. and L.V.V. are indebted to FWO, Belgium. 


\section{References}

[1] A. Benninghoven, A. Müller, Phys. Lett. A 40 (1972) 169.

[2] A. Benninghoven, A. Müller, Surf. Sci. 39 (1973) 416.

[3] H.W. Werner, Surf. Sci. 47 (1975) 301.

[4] D. Briggs, A. Brown, J.C. Vickerman, Handbook of Static Secondary Ion Mass Spectrometry (SIMS), Wiley, Chichester, UK, 1989.

[5] J.C. Vickerman, D. Briggs, A. Henderson, The Static SIMS Library, Part 1, Surfacespectra Ltd, Manchester, UK, 1998.
[6] L. Van Vaeck, A. Adriaens, R. Gijbels, Mass Spectrom. Rev. 18 (1999) 1.

[7] A. Adriaens, L. Van Vaeck, F. Adams, Mass Spectrom. Rev. 18 (1999) 48.

[8] R. Van Ham, A. Adriaens, L. Van Vaeck, F. Adams, in: Secondary Ion Mass Spectrometry SIMS XII, Elsevier, Submitted. 